() Мормоль І.А., Борзих О.А., Кайдашев І.П.

УДК 616-001:616.25-003.215

\title{
ОСОБЛИВОСТІ ТЕРАПЕВТИЧНОГО ЗАБЕЗПЕЧЕННЯ ХВОРИХ ІЗ ПОЛІТРАВМОЮ*
}

\author{
Мормоль І.А., Борзих О.А., Кайдашев І.П.
}

Вищий державний навчальний заклад України «Українська медична стоматологічна академія», м. Полтава

Актуальность вопроса своевременной диагностики и лечения политравмы на сегодняшний день остается важным. Политравма - серьезный патологический процесс, который включает одновременное начало и развитие нескольких патологических состояний и характеризуется основными нарушениями всех видов обмена веществ, изменениями центральной нервной системы, сердечно-сосудистой и дыхательной. Данный клинический случай доказывает нам целесообразность разработки персонифицированного подхода к ведению пациентов с политравмой, используя индивидуальные алгоритмы.

Ключевые слова: политравма, гемопневмоторакс, тактика лечения

Політравма - сукупність травм, які характеризуються значними змінами структури та функції органів i систем органів. Крім механічних пошкоджень, на стан постраждалого може мати вплив ряд інфекційних ускладнень. Політравми відрізняються особливою важкістю клінічних проявів, що супроводжуються розладом життєво-важливих функцій організму, складністю діагностики та лікування, великим процентом інвалідності і високою летальністю. Подібні пошкодження часто супроводжуються травматичним шоком, великою крововтратою, розладом кровообігу і дихання, інколи термінальним станом. При політравмі перебіг травматичної хвороби особливо важкий, а характер домінуючого пошкодження може змінюватися $[1,2]$.

Термін «політравма» $€$ збірним поняттям, що включає такі види пошкоджень: множинні, поєднані і комбіновані.

До множинних механічних травм відносять пошкодження двох і більш внутрішніх органів в одній порожнині (поранення тонкої і товстої кишок, розрив печінки і селезінки, пошкодження обох нирок), травми в межах двох і більш анатомо-функціональних утворень опорно-рухової системи (перелом стегна, перелом обох п'яткових кісток).

Поєднана травма - пошкодження внутрішніх органів в різних порожнинах (травма легені і печінки, струс головного мозку і травма нирки), або пошкодження внутрішніх органів і опорно-рухового апарату (пошкодження органів грудної порожнини і перелом кісток кінцівок, черепно-мозкова травма, пошкодження тазових кісток та ін.).

Комбінована травма - це одночасна дія на потерпілого двох і більш факторів: перелом і опік стегна; гостра променева хвороба і перелом хребта. Іншими словами, механічні травми можуть входити до складу комбінованих пошкоджень як один із складових компонентів [3].

Політравма перш за все характеризується пошкодженням опорно-рухової системи. За даними деяких авторів вона переважає у молодих людей (53\%, переважно чоловіки) віком 14-45 років. Основною причиною травмування є дорожні аварії - 80,6\%.

При політравмі множинні ушкодження опорнорухової системи уражають нижні кінцівки у 49,4\% ви- падках, верхні - у 33,2\%, таз - у 14,1\%. Крім цих травм $75 \%$ пацієнтів мають супутні пошкодження: голова і мозок - у 92,2\%, грудна клітка - у 31,5\%, живіт - у 21,3\%.

При лікуванні хворих із політравмою найважливішими принципами $€$ запобігання смерті пацієнта від шоку і крововтрати та запобігання ускладненням у ранньому періоді від поліорганної недостатності та сепсису [4].

За даними ВООЗ щоденно внаслідок травм гине близько 16 тис. осіб, щорічно - 300 тис. працездатних людей, а 7-8 млн. стає інвалідами.

За останні 10 років смертність від травм в Україні збільшилася на 38,7\%. За даними МОЗ України від травм щорічно гине 31-44 тис. осіб, з них - 20-25\% від поєднаної травми.

Частота політравми в останні роки складає 5,535\% серед всіх травмованих пацієнтів.

Летальність при політравмі складає 12,2-63,4\%, 3 них: в перші 24-48 годин помирає $65,1-70,0 \%$ потерпілих (з них - 35,0\% в перші 15 хвилин від моменту травми).[8]

В економічно розвинутих країнах травматизм займає 3 місце серед причин смертності після онкологічних та серцево-судинних захворюваннях.

Поліморфізм пошкоджень не дозволяє в повному об'ємі регламентувати об'єм і порядок застосування інструментальних обстежень. Загалом діагностична програма включає:

1. загальноклінічні обстеження;

2. катетеризацію сечового міхура;

3. обробка ран з їх ревізією;

4. ультразвукове дослідження;

5. рентгенографрію ОГК і черевної порожнини;

6. торако- і лапароцентез;

7. діагностичну лапароскопію.

Орієнтовний перелік першочергових діагностичних тестів у пацієнта з нестабільним станом наступний:

1. визначення симптомів дислокації мозку;

2. торакопункція, торакоцентез;

3. лапароцентрез, лапароскопія.

Існує велика кількість шкал для оцінки важкості пошкодження: AIS (Abreviated Index Severity), ISS (Injury Severity Score), ЦИТО, NISS (New Injury Severity

* Цитування при атестації кадрів: Мормоль І.А., Борзих О.А., Кайдашев І.П. Особливості терапевтичного забезпечення хворих із полі травмою. // Проблеми екології і медицини. - 2018. - Т. 22, № 1-2. - С. 23-27. 
Score), ICISS (International Classification Injury Severity Score), OIS (Organ Injury Scaling) та інші.

Серед числених шкал оцінки важкості травми найбільш вживане $є$ шкала TRISS (Injury Severity Score \pm Revised Trauma Score = Trauma Injury Severity Score). В теперешній час важливості набувають особливості терапевтичного забезпечення хворих із політравмою. Для ілюстрації наведено клінічний випадок.

Хворий чоловік, 1974 р.н., госпіталізований 14.11.16 р. о 18:00 год. в реанімаційне відділення міської лікарні зі скаргами на болі в грудній клітині, кашель, задишку. 3 анамнезу відомо, що отримав травму грудної клітини при пірнанні у воду. При об'єктивному огляді загальний стан хворого тяжкий. В свідомості, адекватний. Шкіра та видимі слизові блідорожеві, вологі на дотик. Дихання самостійне, ЧД - 22 в 1 хв. При аускультації в легенях вислуховуються ослаблене дихання та вологі хрипи, більше справа. Перкуторно межі серця в межах вікової норми. Серцеві тони ритмічні, ослаблені, глухі. АТ - 100/60 мм.рт.ст., PS - 106 уд. за 1 хв., $\mathrm{SpO}_{2}-87 \%$. Живіт м'який, безболісний.

В загальному аналізі крові: еритроцити $4,9 \cdot 10^{12} / л$; лейкоцити $-15,2 \cdot 10^{9}$ /л; швидкість зсідання еритроцитів (ШЗЕ) - 4 мм/год, концентрація гемоглобіну $(\mathrm{Hb})-158$ г/л; кольоровий показник (КП) - 0,96; лейкоцитарна формула: паличкоядерні (п/я) - 3\%; сегментоядерні (с/я) - 81\%; еозинофіли - 1\%; лімфоцити - 10\%; моноцити - 5\%.

В біохімічному аналізі крові: білірубін: загальний 16,5; прямий - 3,1; непрямий - 13,4 мкмоль/л; креатинін - 80,5 мкмоль/л; сечовина - 4,9 ммоль/л; залишковий азот - 25 мг\%; загальний білок - 66 г/л. Коагулограма: фрібриноген - 1,7 г/л, протромбін - 61\%.

Результати ЕКГ: синусова тахікардія, ЧСС - 128 уд. в 1 хв., ЕВС не відхилена. Порушення внутрішньошлуночкової провідності. Ознаки гіпертрофії міокарду лівого шлуночка.

Дані УЗД органів черевної порожнини та нирок: печінка: не збільшена, розміщення - типове, форма звичайна, контури - чіткі, розміри: права доля - 12,6 см, ліва доля - 6,2 см, паренхіма: ехогенність - нормальна, структура - однорідна. Внутрішньопечінкові протоки - нерозширені, стінки - не змінені, холедох 0,4 см, стан судин - не розширені. Жовчний міхур: розміщення - типове, форма - овоїдна, товщина стінки - 0,2 cм, ущільнена, осадок жовчі на $1 / 2$ міхура. Підшлункова залоза не збільшена. Розміри: голівка - 2,8 см, тіло - 1,3 см, хвіст - 2,7см. Контури - рівні, ехогенність - нормальна, структура - неоднорідна. Вірсунгов проток - не розширений. Селезінка не збільшена, контури - чіткі, ехогенність - нормальна, структура - однорідна. Права нирка: не збільшена, контури - чіткі, паренхіма - 1,5см., площа центр. комплексу збільшена, 1,9 см, за рахунок мікролітів 0,1 см. Ліва нирка: не збільшена, контури - чіткі, паренхіма - 1,8 см., площа центр. комплексу - збільшена, 2,0 см, за рахунок мікролітів 0,1 см. Наявність вільної рідини в черевній порожнині: не знайдено. Заключення: УЗО хронічного холецисто-панкреатиту, сечокислого діатезу, вільної рідини в черевній порожнині не виявлено.

УЗД не вдається провести ретельно по технічним причинам (із-за несправності апарату), але не можна виключити пневмоторакс грудної клітини або наявність підшкірної емфріземи.
Результати рентгенографії органів грудної клітини: підсилення легеневого малюнка. Корені розширені. Синуси вільні. Cor - збільшено в поперечнику.

Діагноз при госпіталізації: Тяжка комбінована травма. Тяжка поєднана краніо-торакальна травма. ЗЧМТ: струс головного мозку. Закрита травма грудної клітини: перелом III ребра справа, двобічний гемопневмоторакс. Забій серця та легень. Баротравма легень. Двобічний пульмоніт.

Призначено лікування: глюкоза, амікацин, максіцин, лазолван, лазікс, тугіна, препарати калію, контролок. Рекомендовано: консультація торакального хірурга, пульмонолога, кардіолога, травматолога та проведення комп'ютерної томографії (КТ) органів грудної клітини, бронхоскопії.

Проведено пункцію та дренування плевральної порожнини справа.

На 15.11.16 р. загальний стан хворого тяжкий, в свідомості, доступний продуктивному контакту. Скарги на біль в грудній клітині, задуху, виражену загальну слабкість. Дихання - ШВЛ через інтубаційну трубку. $\mathrm{SpO}_{2}-98 \%$. Аускультативно в легенях - жорстке дихання, в нижніх відділах ослаблене. Через дренажі 3 плевральних порожнин виділяється геморагічна рідина справа - 70 мл, зліва - 100 мл. Гемодинаміка стабільна. Тони серця ритмічні, ослаблені. Живіт без особливостей.

В загальному аналізі крові зростає рівень лейкоцитів до 19,0·10/л та знижується рівень $\mathrm{Hb}-105$ г/л. Коагулограма: фрібриноген - 2,87 г/л, протромбін $101,4 \%$.

В біохімічному аналізі крові зростає рівень креатиніну до 109 мкмоль/л, залишкового азоту до 52 мг\% та знижується рівень загального білка до 59 г/л. Отримані результати аналізу крові на електроліти: калій 4,32 ммоль/л; натрій - 147,7 ммоль/л; хлоридів - 101 ммоль/л; кальцій - 1,0 ммоль/л.

Результати УЗД серця: УЗ ознаки зниження скоротливої здатності міокарду, забій серця.

Результати ЕКГ: синусова тахікардія, ЧСС - 103 уд в 1 хв, ЕВС не відхилена. Порушення внутрішньошлуночкової провідності. Ознаки гіпертрофії міокарду лівого шлуночка.

Бронхофіброскопія. Заключення: кровотеча з правого бронха.

Пацієнт оглянутий торакальним хірургом. Встановлений діагноз: Тяжка комбінована травма. Тяжка поєднана краніо-торакальна травма. ЗЧМТ: струс головного мозку, забій лицевого черепа. ЗТГ: перелом III ребра справа; 2 - х сторонній гемопнемоторакс; забій серця та легень. Баротравма легень. Двосторонній пульмоніт. Рекомендовано провести КТ головного мозку та грудей, бронхоскопію, консультацію кардіолога.

Проведенно переливання свіжозамороженої плазми в кількості 300,0 мл.

На 16.11.16 р. загальний стан пацієнта вкрай тяжкий, в стані медикаментозної седаціі, дихання - ШВЛ через інтубаційну трубку. 3 плевральних порожнин по дренажам виділяється геморагічний ексудат: зліва 100 мл, справа - 190 мл. $\mathrm{SaO}_{2}-92 \%$. Гемодинаміка стабільна.

В загальному аналізі крові продовжує зростати кількість лейкоцитів до $16,7 \cdot 10^{9} /$ л (за рахунок п/я $12 \%)$ та Ш3Е - 12 мм/год.

В біохімічному аналізі крові залишається підвищений рівень сечовини до 12,0 ммоль/л та залишкового азоту до 46 мг\%, інших суттєвих змін не виявлено. 
Коагулограма: фрібриноген - 4,99 г/л, протромбін $59,1 \%$.

Результати ЕКГ: синусова тахікардія, ЧСС - 100 уд в 1 хв, синусова тахікардія, передсердна екстрасистолія, ЕВС вертикальна. У порівнянні з ЕКГ від 15.11.16 р. спостерігається погіршення коронарного кровотоку по задній стінці лівого шлуночка.

Результати УЗД серця: УЗО помірного зниження скоротливої здатності міокарду, гіпертрофії зСлШ. В правому синусі грудної клітини - гідроторакс.

Результати рентгенографії органів грудної клітини: справа - пневмоторакс (легеня зменшена на 2/3 свого об'єму). Підшкірна та м'язова емфрізема. Зліва - масивні інфільтрати зливного характеру.

Проведенно переливання свіжозамороженої плазми в кількості 300,0 мл.

Результати бронхоскопії: кровотеча 3 правого та лівого бронхів. Двобічний дифузний ендотрахеїт.

Загальний стан хворого залишається вкрай тяжким і на 17.11.16 р. Пацієнт знаходиться в стані постійної медикаментозної седації. Дихання апаратне ШВЛ, $\mathrm{SpO}_{2}-96 \%$. Аускультативно в легенях - жорстке дихання, велика кількість сухих та вологих хрипів, справа - різко ослаблене. Дренажна система з обох плевральних порожнин функціонує, з правої та лівої легені виділяється по 300 мл геморагічного ексудату.

В загальному аналізі крові зростає кількість лейкоцитів до $21,2 \cdot 10$ /л та ШЗЕ - 17 мм/год, знижується Нb до 100 г/л та КП - 0,85.

В біохімічному аналізі крові суттєвих змін за добу не виявлено. Рівень електролітів в крові зростає: калій - 4,55 ммоль/л; натрій - 152,5 ммоль/л; хлоридів 112,8 ммоль/л; кальцій - 1,20 ммоль/л. Коагулограма: фрібриноген - 7,71 г/л, протромбін - 90,0\%.

Результати ФГДС: даних за травму ШКТ не виявлено.

Результати ЕКГ: синусова тахікардія, ЧСС - 103 уд в 1 хв. У порівнянні з ЕКГ від 16.11.16 р. спостерігається зміна ЕВС (зміщення вліво) - вірогідно зміна провідності по передній гілці лівої ніжки п. Гіса.

Результати рентгенографії органів грудної клітини: динаміка негативна, зберігається вогнищева інфільтрація на всі легеневі поля обох легень. Cor - без особливостей. Збільшується підшкірна емфізема.

Проведенно переливання свіжозамороженої плазми в кількості 300,0 мл. Результати бронхоскопії: кровотеча з сегментарних бронхів правої легені. Двобічний дифузний ендотрахеїт II ст.

На 18.11.16 р. в об'єктивному статусі хворого змін не має, хворому проводять парентеральне харчування через позагастральний зонд. Проведена заміна інтубаційної трубки. Через дренажі з кожної плевральної порожнини виділяється по 400 мл геморагічної рідини. $\mathrm{SpO}_{2}-98 \%$.

В загальному аналізі крові зберігається лейкоцитоз - 17,3 ×10\%, підвищення ШЗЕ - 11 мм/год та зниження $\mathrm{Hb}-112$ г/л.

В біохімічному аналізі крові клінічно-значимих змін у порівнянні з минулою добою не виявлено. Коагулограма: фрібриноген - 4,99 г/л, протромбін - 53,6\%.

Результати бронхоскопії: кровотеча з сегментарних бронхів нижньої частки правої легені. Двобічний дифузний ендотрахеїт.

Враховуючи стан хворого і тривалий період перебування на ШВЛ хворому 19.11.16 р. була виконана трахеостомія, через яку санується велика кількість геморагічного харкотиння. А через дренажі з плевра- льних порожнин продовжує виділяться рідина з геморагічним компонентом: справа в кількості - 500 мл., зліва - 500 мл. $\mathrm{SpO}_{2}-95 \%$.

В загальному аналізі крові: ер. $-4,2 \times 10^{12} / л$; лейк. $18,6 \times 10^{9}$ /л; ШЗЕ - 5 мм/год, Нb - 128 г/л; КП - 0,95; п/я - 8\%; с/я - 70\%; e-1\%; л-15\%; м - 6\%.

В біохімічному аналізі крові: білірубін: загальний 13,5 мкмоль/л; прямий - 3,1 мкмоль/л; непрямий - 10,4 мкмоль/л; креатінін - 80,1 мкмоль/л; сечовина - 6,3 ммоль/л; залишковий азот - 29 мг\%; загальний білок - 65 г/л; калій - 4,7 ммоль/л; натрій - 143,8 ммоль/л; хлоридів - 100,7 ммоль/л. Коагулограма: фрібриноген $-4,5$ г/л, протромбін - 52\%.

На 20.11.16 р. загальний стан хворого тяжкий, в стані постійної медикаментозної седації. Дихання ШВЛ, $\mathrm{SpO}_{2}-95 \%$. Через дренажі з плевральних порожнин виділяється геморагічна рідина справа - 500 мл, зліва - 500 мл. Гемодинаміка стабільна. Тони серця ритмічні, ослаблені. Живіт без особливостей.

В загальному аналізі крові зберігається лейкоцитоз до $11,7 \cdot 10^{9} / л$, підвищення ШЗЕ - 19 мм/год, Нb 122 г/л; КП - 0,91; п/я - 12\%; с/я - 72\%; е - 1\%; л $13 \% ; \mathrm{m}-2 \%$.

В біохімічному аналізі крові спостерігається підвищений рівень залишкового азоту - 30 мг\%. Коагулограма: фрібриноген - 4,6 г/л, протромбін - 57\%.

На 21.11.16 р. загальний стан пацієнта залишається вкрай тяжким, в стані постійної медикаментозної седації. Дихання апаратне - ШВЛ, $\mathrm{SpO}_{2}-96 \%$. З'явилася пастозність верхніх та нижніх кінцівок, набряк мошонки.

В загальному аналізі крові спостерігаються ознаки

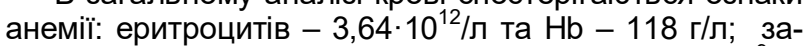
лишається підвищений рівень лейкоцитів - 10,6 $10 \%$ /л; ШЗЕ - 40 мм/год, п/я - 33\%.

В біохімічному аналізі крові - підвищений рівень залишкового азоту - 51 мг\% та сечовини - 13,6 ммоль/л. Коагулограма: фрібриноген - 7,71 г/л, протромбін - 77,6\%.

Результати УЗД серця: Cor не локується - артефракти (вузьке УЗ вікно), вірогідно за рахунок пневмотораксу або підшкірної емфіземи.

Проведенно переливання свіжозамороженої плазми в кількості 300,0 мл.

Результати бронхоскопії: Двобічний дифузний ендотрахеїт.

Хворий оглянутий урологом і був виставлений діагноз: рефлекторна затримка сечі. Уретріт. Уретральний катетер. Набряк мошонки. Рекомендовано продовжити антибактеріальну та сечогінну терапію та контроль діурезу.

На 22.11.16 р. загальний стан хворого тяжкий, в стані постійної медикаментозної седації. Дихання ШВЛ, $\mathrm{SpO}_{2}-93 \%$. Температура тіла підвищилась до $38,0{ }^{\circ} \mathrm{C}$. Через трахеостомічну трубку санується геморагічне харкотиння. Через дренажі з плевральних порожнин виділяється геморагічна рідина справа - 500 мл, зліва - 500 мл. Гемодинаміка стабільна. Тони серця ритмічні, ослаблені. PS - 120 уд/хв. Живіт без особливостей.

В загальному аналізі крові підвищений рівень лейкоцитів 19,6·10\% /л; ШЗЕ - 35 мм/год, п/я - 22\% та зниження $\mathrm{Hb}-115$ г/л.

В біохімічному аналізі крові - підвищений рівень залишкового азоту - 56 мг\% та сечовини - 15,2 ммоль/л. Коагулограма: фібриноген - 10,17 г/л, протромбін $-68,5 \%$. 
На 23.11.16 р. загальний стан хворого тяжкий, в стані постійної медикаментозної седації. Дихання ШВЛ. Через дренажі з плевральних порожнин виділяється геморагічна рідина справа - 500 мл, зліва - 500 мл. Гемодинаміка стабільна. Тони серця ритмічні, ослаблені. Живіт без особливостей.

В загальному аналізі крові: лейкоцитів $-51,0 \cdot 10^{9} / л$; ШЗЕ - 41 мм/год, Нb - 104 г/л; КП - 0,93; п/я - 18\%; с/я - 52\%; е-6\%; л-16\%; м - 2\%, присутня токсична зернистість нейтрофрілів. В біохімічному аналізі крові: креатинін - 237 мкмоль/л; сечовина - 25,6 ммоль/л; залишковий азот - 87 мг\%; загальний білок - 46 г/л. Коагулограма: фрібриноген - 7,71 г/л, протромбін $80,8 \%$.

Пацієнт повторно оглянутий торакальним хірургом о 15:00 год. 23.11.16 р.: у пацієнта рецидивуючий масивний гемопневмоторакс, пацієнту виконано редренування гемопневмотораксу справа, замінено дренажі. При активній аспірації вдалося розправити праву легеню, що супроводжувалося покращенням кардіореспіраторих показників. В 16:39 год. при відключенні електровідсмоктувача легеня складається, йде масивний вихід повітря. За життєвими показниками хворому проведена екстренна торакотомія. При проведенні проведенні передньо-бокової торакотомії справа зафіксовано зупинку серця. Не зважаючи на проведення реанімаційних заходів в 18:00 год. зафріксовано біологічну смерть.

Посмертний епікриз:

Вкрай тяжка комбінована травма. Вкрай тяжка краніоторакальна травма. ЗЧМТ: струс головного мозку, множинні забійні рани лицевого черепа. ЗТГ: множинні фррагментарні переломи II-III- IV ребер справа; 2 - х сторонній гемопнемоторакс, двостороння контузія легень; контузія серця з розривом перекарда. Травматичний шок III (14.XI.16). Постравматична двостороння пневмонія. РДС II тип. ДН ІІІ. Рецидивуючий некупіруючий правобічний від 23.XI.2016 пневмоторакс. Баротравма легень від 14. XI.16.

\section{Судово-медичний діагноз}

Закрита травма грудної клітини. Синець на лівій передньо-боковій поверхні грудної клітини. Обширні крововиливи в м'які тканини грудної клітини в проекції 2-8 ребер, від середньо - ключичної до середньо пахвинної ліній справа та 2-7 ребер, від середньо ключичної до задньо -пахвинної ліній зліва. Множинні переломи грудини та ребер по декільком анатомічним лініям. Розрив серцевої сумки по лівій боковій поверхні. Крововилив в епікард лівого шлуночка серця, на рівні передньої коронарної артерії. Обширні крововиливи та розриви верхньої та середньої доль правої легені. Гостра легенево-серцева недостатність. Серозно-геморагічне просочування 3 застійною пневмонією в нижній долі правої легені. Фібринозний плеврит правої легені. Серозне просочування легень з дрібними вогнищами гострої емфіземи. Серозний епікард. Незначний коронаросклероз. Навколо судинний кардіосклероз. Нерівномірне кровонаповнення з дистрофрією та вогнищевою фрагментацією кардіоміоцитів в набухлому міокарді. Венозне повнокрів'я, паренхіматозна дистрофія внутрішніх органів. Стан після надання медичної допомоги та реанімаційних заходів.

Гемопневмоторакс (Haemopneumothorax) - це наявність повітря і крові в плевральній порожнині, що виникає зазвичай в результаті травми і являється ре- зультатом кровотечі із судин легень, внутрішньогрудних гілок великих судин (аорта), грудної стінки, середостіння, серця або діафрагми $[5,6]$.

На відміну від пневмотораксу, механізм виникнення якого схожий з гемотораксом, при скупченні крові в плевральній порожнині на перший план виходять симптоми дихальної недостатності, а гіповолемічний симптомокомплекс часто ускладнюється розвитком ознак геморагічного шоку i летальним результатом. Клінічна картина при гемотораксі залежить від обсягу крові, що вилилася в плевральну порожнину, наявності або відсутності порушення цілісності легеневої тканини, а також від стану структур середостіння $[7,8]$.

Травматичний гемоторакс практично в 70-80\% випадків обумовлений переломами ребер різної локалізації зі зміщенням кісткових відламків. Частота даної патології становить не менше $25 \%$ серед усіх випадків торакальної травми. Розрізняють також гемоторакс малий (рівень рідини нижче кута лопатки, ії̈ обсяг - до 500мл), середній (рівень рідини до кута лопатки, її обсяг - до 1000 мл) і великий (рідина займає всю або майже всю плевральну порожнину, ії̈ обсяг понад 1000мл). Гемоторакс може бути із зупиненим і 3 триваючим кровотечею $[9,10]$.

Гемоторакс відноситься до розряду невідкладних нозологічних хвороб, що потребують ранньої діагностики та екстренного медичного втручання. По статистиці діагноз гемопневмоторакс ставиться чоловікам на $67.66 \%$ частіше, ніж жінкам. Смертність у чоловіків при гемопневмотораксі складає 0,76\%, а у жінок $-1,07 \%$. В групу ризику при захворюванні на гемопневмоторакс потрапляють чоловіки у віці 65-69 років і жінки у віці 80-84 років.

Серед всіх відомих лабораторних та інструментальних методик діагностики гемоторакса найбільш доцільними є: променеві методи візуалізації (рентгеноскопія, ультразвукове сканування плевральних порожнин, комп'ютерна томографія і магнітно-резонансна томографрія), бронхоскопія з супутньою біопсією, цитологічний аналіз харкотиння з метою визначення наявності атипових клітин, діагностичний торакоцентез 3 проведенням проб Ривилуа-Грегуара і Петрова $[11,12]$.

Стандартна рентгенографія дозволяє оцінити лише фракт наявності рівня рідини в плевральній порожнині і виявити обсяг накопиченої крові. Так, наявне тотальне затемнення всієї половини грудної клітки свідчить про те, що в плевральній порожнині знаходиться не менше двох літрів крові, а якщо верхня межа затемнення знаходиться на рівні заднього відрізка другого ребра, то об'єм крові становить від одного до двох літрів. Спеціаліст ультразвукової діагностики оцінює наявність навіть мізерної кількості крові.

Після визначення можливої наявності крові в плевральній порожнині доцільно проведення діагностичного плевроцентеза 3 аспірацією вмісту плевральної порожнини. Дана маніпуляція проводиться з метою встановлення тривалості кровотечі та ознак інфікування плевральних листків. Критерієм інорікованого гемоторакса є позитивна проба Петрова, при якій виявляється зниження прозорості та наявність осаду аспірованої крові. При підозрі на інфікованість плевральної порожнини необхідно виконати не тільки цитологічне, але і бактеріальне дослідження аспірату. Визначальною ознакою триваючої внутрішньо-плевральної кровотечі $€$ пози- 
тивна проба Ривилуа-Грегуара, яка передбачає наявність ознак згортання крові $[13,14]$.

Сучасна тактика лікування гемопневмоторакса передбачає швидке видалення крові та газу із порожнини плеври 3 метою розправлення легені. 3 цією ціллю дренують плевральну порожнину методом активної аспірації через дренаж за допомогою електроотсоса.

Показанням до проведення торакотомії $€$ поранення легені, довготривала внутрішньоплевральна кровотеча, неефективність консервативної тактики. Усунення гемо пневмотораксу і розправлення легені в перші 3-5 діб сприяють попередженню розвитку емпієми плеври і відновленню функції легень в повному обсязі.

Лікуванням пацієнта 3 гемотораксом повинні займатися лікарі різного профрілю: хірург, пульмонолог, i реабілітолог. Успіх від застосування тих чи інших лікувальних маніпуляцій при гемотораксі залежать, насамперед, від ранньої діагностики цього грізного для життя пацієнта стану, а також своєчасно наданої першої кваліфікованої допомоги.

Лікування будь-якої форми гемоторакса повинно проводитися якомога раніше, так як кров являє собою одну 3 найбільш сприятливих поживних середовищ для розмноження хвороботворних мікроорганізмів. Найбільш частіше зустрічається, як збудник інфікованого гемоторакса, $€$ облігатна анаеробна фрлора $[15,16]$.

Консервативні методи лікування із застосуванням антибактеріальних і протизапальних лікарських засобів застосовуються тільки у випадку малого гемоторакса, не має виражених розладів здоров'я пацієнта. Консервативне лікування повинне проводитися під обов'язковим рентгенологічним контролем. Оптимальними строками розсмоктування малого гемоторакса вважається від двох тижнів до 1 місяця. 3 метою прискорення процесу розсмоктування кров'яних згустків хворим з ознаками згорнутого гемоторакса доцільно призначати протеолітичні ферменти парентерально (Хімотрипсин 25 мг внутрішньом'язово 1 раз на добу курсом не менше 15 ін'єкцій), а також за допомогою безпосереднього зрошення плевральних порожнин розчинами урокінази, стрептокінази.

Таким чином, для надання кваліфікованої медичної допомоги хворим з політравмою необхідно розробити персоніфікований підхід із складанням індивідуальних алгоритмів із залученням мультидисциплінарної команди.

\section{Література:}

1. Кавалерский Г. М., Гаркави А. В. 7.1 Классификация политравм. Особенности клинического течения и диагностики // Медицина чрезвычайных ситуаций. Хирургия катастроф.. - Москва: Медицинское информационное агентство, 2015. - С. 165 . -376 с.
2. Філь А. Ю., Філь Ю. Я. Сучасна тактика надання допомоги при скелетній травмі постраждалим із політравмою (огляд літератури) // Травма. - 2014. N 1. - C. $125-128$

3. Гур'єв С. О., Танасієнко П. В. Сучасна класифікація інфекційних ускладнень у постраждалих із політравмою // Травма. - 2013. - Т. 14, № 6. - С. 2123.

4. Pathophysiology of polytrauma - Keel, M. \& Trentz O. Injury, Volume 36, Issue 6, Pages 691-709

5. Ahmad T., Ahmed S.W. Soomro N.H., Sheikh K.A. Thoracoscopic evacuation of retained posttraumatic hemothorax // Journal of the College of Physicians and Surgeons Pakistan.- 2013. - Vol. 23 (3). - P. 234-236.

6. de Rezende-Neto J.B., PastoreNeto M., Hirano E.S., Rizoli S., Nascimento B. Jr., Fraga G.P. Management of retained hemothoraces after chest tube thoracostomy for trauma /I Rev Col Bras Cir. - 2012 -. Vol. 39 (4). - P. 344-349.

7. DuBose J., Inaba K., Demetriades D., Scalea T.M., et al Management of post-traumatic retained hemothorax: a prospective, observational, multicenter AAST study // Trauma Acute Care Surg. - 2012. - Vol. 2 (1). P. 11-22.

8. Hsing-LinLin, Wen-Yen Huang, ChyanYang, ShihMinChou et al. How early should VATS be performed for retained hemothorax in blunt chest trauma? // Injury. 2014. - Vol. 45 (9). - P. 13591364.

9. Karmy-Jones R., Holevar M., Sullivan R.J., Fleisig A., Jurkovich G.J. Residual hemothorax after chest tube placement correlates with increased risk of empyema following traumatic injury // Can Respir J. - 2008. - Vol. 15 (5). - P. 255-258.

10. Meyer D.M., Jessen M.E., Wait M.A., Estrera A.S. Early evacuation of traumatic retained hemothoraces using thoracoscopy: a prospective, randomized trial // Ann Thorac Surg. - 1997. - Vol. 64(5). - P. 1396-1400.

11. Morales Uribe C.H., Villegas Lanau M.I., Petro Sánchez R.D. Best timing for thoracoscopic evacuation of retained post-traumatic hemothorax // SurgEndosc. - 2008. - Vol. 22 (1). - P. 91-95.

12. Navsaria RH., Vogel R.J., Nicol A.J. Thoracoscopic evacuation of retained posttraumatic hemothorax. Ann ThoracSurg. - 2004. - Vol. 78 (1). - P. 282-285.

13. Nathan T.M., Oliver L.G., Bryan R.C., Jose J.D. et al. $\mathrm{Pтa}^{\wedge \wedge}$ Management Guidelines for Management of Hemothorax and Occult Pneumothorax // The Journal of Trauma Injury, Infection, and Critical Care. - 2011. - Vol. 70 (2). - P. $510-518$

14. Smith J.W., Franklin G.A., Harbrecht B.G., Richardson J.D. Early VATS for blunt chest trauma: a management technique underutilized by acute care surgeons // Trauma. - 2011. - Vol. 71 (1). - P. 105-107.

15. Abakumov, A.M. Travmaticheskiy Svernuvshiysya Gemotoraks (diagnostika I lechenie) Dis. ... Kand. Med.nauk [Traumatic Hemothorax Coagulated Dissertation of the Candidate of Medical Sciences]. - Moscow, 2003. 168 p.

16. Dergunova, S.A. Optimizatsiya Khirurgicheskoy Taktiki Pri Razlichnykh Vidakh Gemotoraksa Dis. ... Kand. Med.nauk [Optimization of Surgical Tactics for Different Kinds of Hemothorax Dissertation of the Candidate of Medical Sciences]. - Samara, 2005. $130 \mathrm{p}$.

Матеріал надійшов до редакції 26.02.2018 